University of Nebraska - Lincoln

DigitalCommons@University of Nebraska - Lincoln

Publications from USDA-ARS / UNL Faculty

U.S. Department of Agriculture: Agricultural

Research Service, Lincoln, Nebraska

2-26-2016

\title{
A Soil Management Assessment Framework (SMAF) Evaluation of Brazilian Sugarcane Expansion on Soil Quality
}

\author{
Maurício R. Cherubin \\ University of São Paulo, cherubin@usp.br \\ Douglas Karlen \\ USDA-ARS, doug.karlen@ars.usda.gov \\ André L.C. Franco \\ Colorado State University, andre.franco@colostate.edu \\ Carlos E. P. Cerri \\ University of São Paulo, cepcerri@usp.br \\ Cássio A. Tormena \\ State University of Maringá \\ See next page for additional authors
}

Follow this and additional works at: https://digitalcommons.unl.edu/usdaarsfacpub

Cherubin, Maurício R.; Karlen, Douglas; Franco, André L.C.; Cerri, Carlos E. P.; Tormena, Cássio A.; and Cerri, Carlos C., "A Soil Management Assessment Framework (SMAF) Evaluation of Brazilian Sugarcane Expansion on Soil Quality" (2016). Publications from USDA-ARS / UNL Faculty. 1636.

https://digitalcommons.unl.edu/usdaarsfacpub/1636

This Article is brought to you for free and open access by the U.S. Department of Agriculture: Agricultural Research Service, Lincoln, Nebraska at DigitalCommons@University of Nebraska - Lincoln. It has been accepted for inclusion in Publications from USDA-ARS / UNL Faculty by an authorized administrator of DigitalCommons@University of Nebraska - Lincoln. 


\section{Authors}

Maurício R. Cherubin, Douglas Karlen, André L.C. Franco, Carlos E. P. Cerri, Cássio A. Tormena, and Carlos C. Cerri 


\section{A Soil Management Assessment Framework (SMAF) Evaluation of Brazilian Sugarcane Expansion on Soil Quality}

\author{
Maurício R. Cherubin* \\ Dep. of Soil Science \\ "Luiz de Queiroz" College of Agriculture \\ Univ. of São Paulo \\ 11 Pádua Dias Avenue \\ Piracicaba, SP 13418-900 \\ Brazil
}

\section{Douglas L. Karlen* \\ USDA-ARS \\ Natl. Lab. for Agric. and the Environment 2110 University Boulevard Ames, IA 50011}

\section{André L.C. Franco \\ Dep. of Biology \\ Colorado State Univ. \\ 200 West Lake Street \\ Fort Collins, CO 80523}

\section{Carlos E. P. Cerri \\ Dep. of Soil Science \\ "Luiz de Queiroz" College of Agriculture \\ Univ. of São Paulo \\ 11 Pádua Dias Avenue \\ Piracicaba, SP, 13418-900 \\ Brazil}

\section{Cássio A. Tormena \\ Dep. of Agronomy \\ State Univ. of Maringá \\ 5790 Colombo Avenue \\ Maringá, PR 87020-900 \\ Brazil}

\section{Carlos C. Cerri}

Center for Nuclear Energy in Agriculture

Univ. of São Paulo

303 Centenário Avenue

Piracicaba, SP 13400-970

Brazil

Core Ideas:

- The SMAF efficiently detected soil quality changes under Brazilian tropical conditions.

- Soil Quality Index was 0.87 (native vegetation), 0.70 (pasture), and 0.74 (sugarcane).

- Sugarcane expansion improves soil quality, mainly due to increasing soil chemical quality.

- The SMAF-Soil Quality Index was significantly correlated with soil organic $C$ stocks.

- The SMAF is useful for monitoring soil quality changes in Brazilian sugarcane production.
The Soil Management Assessment Framework (SMAF) was developed to evaluate impacts of land use and management practices on soil quality (SQ), but its suitability for Brazilian tropical soils was unknown. We hypothesized that SMAF would be sensitive enough to detect SQ changes associated with sugarcane (Saccharum officinarum L.) expansion for ethanol production. Field studies were performed at three sites across the south-central region of Brazil, aiming to quantify the impacts of a land use change sequence (i.e., native vegetation-pasture-sugarcane) on SQ. Eight soil indicators were individually scored using SMAF curves developed primarily for North American soils and integrated into an overall Soil Quality Index (SQI) and its chemical, physical, and biological sectors. The SMAF scores were correlated with two other approaches used to assess SQ changes, soil organic $C$ (SOC) stocks and Visual Evaluation of Soil Structure (VESS) scores. Our findings showed that the SMAF was an efficient tool for assessing land use change effects on the SQ of Brazilian tropical soils. The SMAF scoring curves developed using robust algorithms allowed proper assignment of scores for the soil chemical, physical, and biological indicators assessed. The SQI scores were significantly correlated with SOC stocks and VESS scores. Long-term transition from native vegetation to extensive pasture promoted significant decreases in soil chemical, physical, and biological indicators. Overall SQI suggested that soils under native vegetation were functioning at $87 \%$ of their potential capacity, while pasture soils were functioning at $70 \%$. Conversions of pasture to sugarcane induced slight improvements in SQ, primarily because of improved soil fertility. Sugarcane soils are functioning at $74 \%$ of their potential capacity. Based on this study, management strategies were developed to improve SQ and the sustainability of sugarcane production in Brazil.

Abbreviations: AGS, macroaggregate stability; BD, bulk density; BG, $\beta$-glucosidase activity; MBC, microbial biomass carbon; SMAF, Soil Management Assessment Framework; SQ, soil quality; SQI, soil quality index; SOC, soil organic carbon; VESS, Visual Evaluation of Soil Structure.

S oil quality or health is a key factor required to achieve sustainable agricultural systems that will meet our increasing demands for food, feed, fiber, and fuels. Therefore, in recent decades SQ has been discussed worldwide and become a major agenda item for the scientific community (Karlen et al., 2008, 2014a). Soil quality was defined as the capacity of a specific kind of soil to function, within natural or managed ecosystem boundaries, to sustain plant and animal productivity, maintain or enhance water and air quality, and support human health and habitation (Karlen et al., 1997). It is a product of inher-

Soil Sci. Soc. Am. J. 80:215-226

doi:10.2136/sssaj2015.09.0328

Open Access.

Received 10 Sept. 2015

Accepted 20 Oct. 2015

*Corresponding authors (cherubin@usp.br; doug.karlen@ars.usda.gov).

(C) Soil Science Society of America. This is an open access article distributed under the CC BY-

NC-ND license (http://creativecommons.org/licenses/by-nc-nd/4.0/). 
ent (e.g., parental material, climate, topography) and anthropogenic (e.g., tillage and cropping systems, land uses) interactions (Karlen et al., 1997). Soil inherent attributes are governed by soil-forming processes and are often relatively unresponsive to soil and crop management practices. On the other hand, dynamic soil properties (e.g., soil organic $\mathrm{C}, \mathrm{pH}$, soil aggregation, microbial biomass activity) are responsive to management practices and/or land use, but their change rates are dependent on the inherent soil attributes (Karlen et al., 1997, 2008).

Land use change processes have transformed a large proportion of the planet's land surface, affecting directly the capacity of soils to function (Foley et al., 2005). Increasing global demand for bioenergy feedstock production has intensified land use changes worldwide (Fischer et al., 2010; Wright and Wimberly, 2013; Mukherjee and Sovacool, 2014; Gasparatos et al., 2015), and especially in Brazil (Lapola et al., 2010; Goldemberg et al., 2014; Bordonal et al., 2015). Brazil is the world's largest sugarcane producer ( 655 million $\mathrm{Mg}$ ), with about $40 \%$ of the global harvest (FAO, 2015). The sugarcane cropped area has expanded from 5.8 to 9.0 Mha between 2005 and 2015 (Companhia Nacional de Abastecimento, 2015) and is projected to increase by 6.4 Mha to meet Brazilian domestic demand for ethanol by 2021 (Goldemberg et al., 2014). Recent expansion has been concentrated in south-central Brazil, and 70\% of the land use change has occurred through conversion of extensive pasturelands (Adami et al., 2012). Sugarcane expansion initiatives have resulted in degraded pastures being subjected to intensive mechanization and inputs of agrochemicals (i.e., lime, fertilizer, and pesticides) that have direct implications on SQ. Therefore, monitoring soil properties (indicators) altered by land use change is crucial for identifying strategies that minimize SQ degradation and its negative implications on ecosystem functioning (Fu et al., 2015; Zornoza et al., 2015).

To implement the concepts of SQ and its assessment, the Soil Management Assessment Framework (SMAF) was initially developed by researchers in the United States on North American soils (Andrews et al., 2004). The SMAF is a quantitative SQ evaluation method that emphasizes a dynamic view of SQ and involves detecting soil response to current or recent management decisions (Andrews et al., 2004; Karlen et al., 2014b). The SMAF uses a three-step process to assess soil quality, including (i) indicator selection (chemical, physical, and biological); (ii) indicator interpretation (nonlinear scoring curves); and (iii) integration into an overall SQ index (SQI). Assessment values are generally expressed as a fraction or percentage of full performance for soil functions such as crop productivity, nutrient cycling, or environmental protection (Andrews et al., 2004; Karlen et al., 2013). Currently, the SMAF has scoring curves or interpretation algorithms for 13 indicators, which encompass physical properties: bulk density (BD), macroaggregate stability (AGS), plant-available water, and water-filled pore space (WFPS); chemical properties: $\mathrm{pH}$, electrical conductivity, $\mathrm{Na}$ adsorption ratio, extractable $\mathrm{P}$ and $\mathrm{K}$; and biological properties: soil organic $\mathrm{C}(\mathrm{SOC})$, microbial biomass $\mathrm{C}(\mathrm{MBC})$, potentially mineralizable $\mathrm{N}$, and $\beta$-glucosidase (BG) activity (Andrews et al., 2004; Wienhold et al., 2009; Stott et al., 2010). These scoring curves were developed and validated using data sets primarily from North America (United States, Canada, and Mexico), with the exception of WFPS (which included data from China), and BG (which included data from Brazil, Argentina, and Italy), considering site-specific controlling factors (climate and/or inherent soil properties) that affect the score of each indicator (Andrews et al., 2004; Wienhold et al., 2009; Stott et al., 2010).

The SMAF has been broadly used in the United States for assessing several situations and factors that affect both agricultural and natural systems at scales ranging from within an experimental field to regional (e.g., Andrews et al., 2004; Wienhold et al., 2006; Zobeck et al., 2008, 2015; Stott et al., 2013; Karlen et al., 2014b; Veum et al., 2015). In addition, SMAF has been tested in other countries around the world, including South Africa (Swanepoel et al., 2015), Ethiopia (Erkossa et al., 2007; Gelaw et al., 2015), and Nepal (Kalu et al., 2015). Data from Brazilian soils was limited in the development and validation of the SMAF, and to our knowledge, no other studies using SMAF as a tool for assessing the impacts of current management practices and land uses on SQ in Brazil have been published. The SMAF could be an important, user-friendly tool for helping farmers, consultants, researchers, and government officials to make immediate and strategic decisions for improving $S Q$ and health and agricultural sustainability.

Therefore, we conducted an on-farm study across the largest sugarcane-producing regions of Brazil to assess the effects of the primary land use change sequence associated with sugarcane expansion (i.e., native vegetation to pasture to sugarcane) on SQ for a wide range of soil textures using SMAF. We hypothesized that: (i) long-term conversion from native vegetation to extensive pasture led to significant SQ degradation; (ii) under current practices, sugarcane production soils are recovering SQ attributes lost when used as pasturelands; and (iii) SQ changes in Brazilian tropical soils under different land use and management systems could be detected by SMAF.

\section{MATERIAL AND METHODS}

\section{Site and Land Use Description}

The study was performed in south-central Brazil, which is the largest sugarcane-producing region of the world. Three strategic and representative sites were studied: (i) Lat_17S located in southern Goiás state, the largest hotspot of sugarcane expansion in Brazil; (ii) Lat_21S located in western São Paulo state, a transition area between traditional and new sugarcane production areas, and (iii) Lat_23S located in south-central São Paulo state, which represents the traditional sugarcane production areas in Brazil. The climate at all three sites has rainfall concentrated in the spring and summer (October-April), while the dry season is in the autumn and winter (May-September). Further details on the location and climate of each site can be found in Table 1 and Cherubin et al. (2015).

A chronosequence was sampled at each site representing three land uses: native vegetation, pasture, and sugarcane, which 
Table 1. Summary of site location, climate, soil, land use history, and management practices for the three sites under land uses of native vegetation, pasture, and sugarcane.

Parameter Description

Lat_17S

Location

Climate

Land use

Soil

Land use history and management practices near Jataí in southwestern Goiás state, Brazil ( $\left.17^{\circ} 56^{\prime} 16^{\prime \prime} \mathrm{S}, 51^{\circ} 38^{\prime} 31^{\prime \prime} \mathrm{W}\right)$

mesothermal tropical (Awa) with a mean annual temperature of $24.0^{\circ} \mathrm{C}$ and annual precipitation of $1600 \mathrm{~mm}$ Native vegetation Pasture

clayey Anionic Acrudox

Cerradão vegetation (Cerrado biome- Brazilian savanna) with dense vegetation compared with the Cerrado sensu stricto

loamy Typic Hapludox

conversion from native vegetation to pasture with tropical grasses of the Brachiaria genus happened in 1980; pasture supports 1.5 animal units $(\mathrm{AU}) \mathrm{ha}^{-1}$ during the year $\underline{\text { Sugarcane }}$

clayey Anionic Acrudox

sugarcane was established on a portion of the pasture in 2009, when the area was plowed and disked, limed with 1.6 $\mathrm{Mg} \mathrm{ha}{ }^{-1}$ of dolomitic lime, and fertilized with $150 \mathrm{~kg} \mathrm{ha}^{-1}$ $\mathrm{P}_{2} \mathrm{O}_{5}$; the crop has been fertilized annually with $110 \mathrm{~kg} \mathrm{ha}^{-1}$

$\mathrm{N}$ and $75 \mathrm{~kg} \mathrm{ha}^{-1} \mathrm{~K}_{2} \mathrm{O}$ and mechanically harvested using a harvester $(\sim 20 \mathrm{Mg})$ and transported by a tractor and trailer $(\sim 10+20 \mathrm{Mg})$

\section{$\underline{\text { Lat } 21 S}$}

Location

Climate

Land use

Soil

Land use history and management practices

near Valparaíso in western São Paulo state, Brazil $\left(21^{\circ} 14^{\prime} 48^{\prime \prime} \mathrm{S}, 50^{\circ} 47^{\prime} 4^{\prime \prime} \mathrm{W}\right)$

humid tropical (Aw), with a mean annual temperature of $23.4^{\circ} \mathrm{C}$ and annual precipitation of $1240 \mathrm{~mm}$

Native vegetation

loamy Typic Rhodudalf

semi-deciduous seasonal forest, comprising a transition between the Atlantic forest and Cerrado vegetation $\underline{\text { Pasture }}$

fine-loamy Typic Kandiudult conversion from native vegetation to pasture occurred in 1980; pasture is composed of tropical grasses of the Brachiaria genus and supports $2 \mathrm{AU}$ ha $^{-1}$ during the year
Sugarcane

loamy Typic Hapludalf

sugarcane was established on a portion of the pasture in 2010, when the soil was prepared by plowing and disking; the crop has been fertilized annually with $11 \mathrm{~kg} \mathrm{ha}^{-1} \mathrm{~N}$, $55 \mathrm{~kg} \mathrm{ha}^{-1} \mathrm{P}_{2} \mathrm{O}_{5}$, and $55 \mathrm{~kg} \mathrm{ha}^{-1} \mathrm{~K}_{2} \mathrm{O}$ (mineral fertilizer); vinasse was applied in 2012 at a rate of $150 \mathrm{~m}^{3} \mathrm{ha}^{-1}$ ( 35 $\mathrm{kg} \mathrm{ha}^{-1} \mathrm{~N} 30 \mathrm{~kg} \mathrm{ha}^{-1} \mathrm{P}_{2} \mathrm{O}_{5}$, and $300 \mathrm{~kg} \mathrm{ha}^{-1} \mathrm{~K}_{2} \mathrm{O}$ ); the crop has been mechanically harvested using similar machines to those described for Lat_17S

$\underline{\text { Lat_23S }}$

Location

Climate

Land use

Soil

Land use history and management practices

near Ipaussu in south-central São Paulo state, Brazil $\left(23^{\circ} 5^{\prime} 8^{\prime \prime} \mathrm{S}, 49^{\circ} 37^{\prime} 52^{\prime \prime} \mathrm{W}\right)$

mesothermal tropical (Awa), with a mean annual temperature of $21.7^{\circ} \mathrm{C}$ and annual precipitation of $1470 \mathrm{~mm}$
Native vegetation

clayey Rhodic Hapludox

local vegetation is similar that described for Lat_21S

\section{Pasture}

clayey Rhodic Kandiudox

conversion from native vegetation to pasture occurred in 1979; pasture is composed of tropical grasses of the Cynodon genus, and supports $1 \mathrm{AU} \mathrm{ha}^{-1}$ during the year

\section{Sugarcane \\ clayey Rhodic Hapludox}

sugarcane was established on a portion of the pasture during the early 1990s using the same mechanical operations as described for the other sites; the crop was fertilized annually with $45 \mathrm{~kg} \mathrm{ha}^{-1} \mathrm{~N}$ (urea) plus $200 \mathrm{~m}^{3} \mathrm{ha}^{-1}$ vinasse ( $\sim 45 \mathrm{~kg}$ $\mathrm{ha}^{-1} \mathrm{~N} 40 \mathrm{~kg} \mathrm{ha}^{-1} \mathrm{P}_{2} \mathrm{O}_{5}$, and $400 \mathrm{~kg} \mathrm{ha}^{-1} \mathrm{~K}_{2} \mathrm{O}$ ) and $25 \mathrm{Mg}$ $\mathrm{ha}^{-1}$ of filter cake and boiler ash $\left(\sim 75 \mathrm{~kg} \mathrm{ha}^{-1} \mathrm{~N}, 55 \mathrm{~kg} \mathrm{ha}^{-1}\right.$ $\mathrm{P}_{2} \mathrm{O}_{5}$, and $30 \mathrm{~kg} \mathrm{ha}^{-1} \mathrm{~K}_{2} \mathrm{O}$ ); the crop has been mechanically harvested using similar machines to those described for Lat_17S, without any burning at this site since 2003 is the most common land use change sequence in south-central Brazil. The synchronic approach (chronosequence) was chosen to represent potential long-term changes occurring in the region due to this land use change. Adjacent land-use areas were sampled to minimize differences in climate, topography, and soil type. A summary of land use history and principal management practices adopted at each site are presented in Table 1.

The soils are typical of the Brazilian tropical region, well drained and highly weathered, with a predominance of the 1:1 clay mineral kaolinite, Fe oxides (goethite and hematite), and $\mathrm{Al}$ oxide (gibbsite) in the clay-size fraction. The soil classification, using criteria outlined by the US soil taxonomy (Soil Survey Staff, 2014), is presented in Table 1.

\section{Soil Sampling and Laboratory Analyses}

Soil samples within each land use (i.e., native vegetation, pasture, and sugarcane) were collected using a consistent grid pattern composed of nine points spaced $50 \mathrm{~m}$ apart, providing a total of 27 sampling points ( 3 land uses $\times 9$ points) for each site or 81 sampling points for the three studied sites. At each sampling point, a small trench ( 30 by 30 by $30 \mathrm{~cm}$ ) was opened to collect undisturbed soil samples from the 0 - to 10-, 10- to 20-, and 20 - to $30-\mathrm{cm}$ depths using metallic cylinders with a volume of about $100 \mathrm{~cm}^{3}$. This provided a total of 243 undisturbed soil samples for soil physical indicator quantification. Around each central trench, composite samples consisting of 12 subsamples were collected, using a Dutch auger, at the same three depths. This provided an additional 243 disturbed soil samples for chemical and biological analyses.

Several soil indicators were analyzed. Chemical indicators included available $\mathrm{P}$ and $\mathrm{K}$ as well as active acidity $(\mathrm{pH}$ in 0.01 mol L ${ }^{-1} \mathrm{CaCl}_{2}$ ), which were measured using analytical methods described by van Raij et al. (2001). Physical indicators included bulk density (BD), calculated by dividing the soil dry mass by the volume of the cylinder $\left(100 \mathrm{~cm}^{3}\right)$, and wet macroaggregate stability (AGS), determined using a vertical oscillator (Yoder 
Model MA-148) with three sieve sizes (2000, 250, and $53 \mu \mathrm{m}$ ) and a speed of 30 oscillations $\mathrm{min}^{-1}$ for $10 \mathrm{~min}$. The AGS (macroaggregation percentage) was calculated by summing the aggregate mass for the $>2000$ - and $>250-\mu \mathrm{m}$ classes, dividing by the total soil mass, and multiplying by 100 . Particle-size distribution was determined using the hydrometer method (Gee and Or, 2002). Biological indicators included: (i) soil organic C (SOC), measured by dry combustion on a LECO CN-2000 elemental analyzer (furnace at $1350^{\circ} \mathrm{C}$ in pure $\mathrm{O}_{2}$ ); and (ii) microbial biomass $\mathrm{C}(\mathrm{MBC})$, measured on three replicates of field-moist samples after fumigating for $24 \mathrm{~h}$ and extracting with $0.5 \mathrm{~mol}$ $\mathrm{L}^{-1} \mathrm{~K}_{2} \mathrm{SO}_{4}$ (Vance et al., 1987); organic $\mathrm{C}$ in the fumigated and unfumigated extracts was measured using a TOC-Vcs/cp analyzer attached to a Shimadzu SSM-5000Abefore calculating the biomass $\mathrm{C}$ with a correction factor of $k=0.33$; and (iii) $\beta$-glucosidase activity (BG), measured using air-dried soil as described by Tabatabai (1994). The concentration of $p$-nitrophenol was determined in triplicate by measuring absorbance at $400 \mathrm{~nm}$ in a spectrophotometer, and the results were expressed in milligrams of $p$-nitrophenol released per kilogram of soil per hour. Both $\mathrm{MBC}$ and $\mathrm{BG}$ activity were analyzed only for the $0-$ to $10-\mathrm{cm}$ soil layer.

Data on SOC stocks and Visual Evaluation of Soil Structure (VESS) scores were used to verify their relationship with SMAF scores. Those measurements were made on soil samples collected at the same sites and sampling times and were previously reported by Franco et al. (2015) and Cherubin et al. (2014, unpublished data), respectively. Briefly, SOC stocks were calculated for each soil layer by multiplying the SOC content of each one by the soil bulk density and the layer thickness $(10 \mathrm{~cm})$. To account for the effect of differing soil bulk densities (due to land use change) on stock comparisons, the stocks within the pasture and sugarcane soils were adjusted to an equivalent soil mass based on measurements for native vegetation (Lee et al., 2009). Subsequently, individual SOC stocks for the 0- to 10-, 10- to 20-, and 20- to 30-cm layers were summed to provide a total SOC stock for the 0 - to 30-cm layer.

Visual Evaluation of Soil Structure is a semi-quantitative approach developed by Ball et al. (2007) and improved by Guimarães et al. (2011) for on-farm assessment of the soil physical and structural capacity to support plant growth. Briefly, a VESS assessment consists of digging out a small trench using a spade and collecting a block of soil (20 by 10 by $25 \mathrm{~cm}$ ) of $\sim 5000 \mathrm{~cm}^{-3}$. The VESS evaluation includes manual breakdown of soil aggregates along their weakness lines, identification of layers having contrasting structure, measurement of layer depths, and assignment of a score by comparing the structure of the sample with the aggregated characteristics proposed by Guimarães et al. (2011). The latter, developed as a VESS key chart, contains descriptions, pictures, and a score for each soil structure quality rating. The criteria take into account to assign the score are related to the shape, size, strength, and visible porosity of the aggregates, as well as biological activity and presence of root interor intra-aggregates. The soil structural quality scores range from
1 (good) to 5 (poor), with 3 being considered a critical limit for suitable plant growth (Ball et al., 2007). More detailed descriptions of the VESS method are available in Ball et al. (2007) and Guimarães et al. (2011).

\section{Soil Management Assessment Framework}

The SMAF was used as a tool to evaluate the land use change effects on SQ. The minimum data set included eight soil indicators ( $\mathrm{pH}, \mathrm{P}, \mathrm{K}, \mathrm{BD}, \mathrm{AGS}, \mathrm{SOC}, \mathrm{MBC}$, and $\mathrm{BG}$ ) for the 0 - to $10-\mathrm{cm}$ layer and six soil indicators $(\mathrm{pH}, \mathrm{P}, \mathrm{K}, \mathrm{BD}, \mathrm{AGS}$, and SOC) for the 10- to 20- and 20- to 30-cm layers. The importance of each one of these indicators to soil functionality has been consistently reported in the literature (e.g., Andrews et al., 2004; Stott et al., 2010; Cardoso et al., 2013; Zornoza et al., 2015). The $\mathrm{pH}$ and available $\mathrm{P}$ and $\mathrm{K}$ provide information about soil acidity and nutrient availability status. Macroaggregate stability and BD indicate the soil structural and physical conditions, which affect soil aeration, water infiltration and storage, and the soil's ability to resist erosion processes. Soil organic C, MBC, and BG were chosen as biological indicators. The SOC plays a crucial role in multiple soil processes including nutrient cycling and storage, soil aggregation, and is a food source for edaphic organisms, while $\mathrm{MBC}$ and $\mathrm{BG}$ indicate the microbiological and biochemical activity of the soils.

This approach is consistent with the general SMAF guidelines, which recommend using a minimum of five indicators with at least one each representing soil chemical, physical, and biological properties and processes (Karlen et al., 2008). These indicators were scored by transforming the mean measured values into 0 to 1 values using previously published algorithms (Andrews et al., 2004; Wienhold et al., 2009; Stott et al., 2010), which were then used to compute an overall SQI for each land use and studied site. Those algorithms account for organic matter, texture, climate, slope, region, mineralogy, weathering class, crop, sampling time, and analytical method effects on the various threshold values. For this study, the organic matter factor class (based on soil classification and used for scoring AGS, SOC, $\mathrm{MBC}$, and $\mathrm{BG}$ ) was 4 (low organic matter content) for all sites. The texture factor class (used for scoring BD, AGS, SOC, MBC, and BG) was 2 (clay content $\sim 17 \%$ ) at Lat_21S and for pasture at Lat_17S and 4 (clay contents $>40 \%$ ) at Lat_17S (except pasture) and Lat_23S. The climate factor (used for scoring SOC, $\mathrm{MBC}$, and $\mathrm{BG})$ was $1\left(\geq 170^{\circ} \mathrm{C} \mathrm{d}\right.$ and $\geq 550 \mathrm{~mm}$ of mean annual precipitation) for all sites. The seasonal factor, impacting $\mathrm{MBC}$ scores, was 2 (sampling in summer-January) for all sites. The Fe oxide content, used for AGS scores, was 1 (Ultisols) for Lat_21S and 2 (other soils) for other sites. The mineralogy factor class, used for scoring $\mathrm{BD}$, was 3 (1:1 clay and $\mathrm{Fe}$ and $\mathrm{Al}$ oxides), and the slope and weathering class factors, used for scoring $\mathrm{P}$, were 2 (2-5\% slope) and 2 (high weathering), respectively, for all sites. The method used to measure extractable $\mathrm{P}$ was resin (Class 5). We changed the resin method factor from 3.1 to 1.25 to avoid overestimating the $\mathrm{P}$ scores under low-P conditions in weathered soils. New crop factors, which affect the $\mathrm{P}$ and $\mathrm{pH}$ scores, needed 
to be added to the SMAF spreadsheet to encompass Brazilian natural vegetation (Cerrado and Atlantic forest), tropical grasses (Brachiaria spp. and Cynodon spp.) and sugarcane. Phosphorus and $\mathrm{pH}$ thresholds for each "new crop" were set up using the literature and expert opinions. Optimum $\mathrm{P}$ and $\mathrm{pH}$ values were: $6 \mathrm{mg} \mathrm{dm}^{-3}$ and 4.5 for Cerrado vegetation; $12 \mathrm{mg} \mathrm{dm}^{-3}$ and 5.5 for Atlantic forest; $13 \mathrm{mg} \mathrm{dm}^{-3}$ and 5.5 for pasture; and $16 \mathrm{mg} \mathrm{dm}^{-3}$ and 6.0 for sugarcane (van Raij et al., 1997). The SMAF algorithms are based on $\mathrm{pH}$ in water; therefore, $\mathrm{pH}$ in $\mathrm{CaCl}_{2}$ was converted to $\mathrm{pH}$ in water by the regression fitted by Ciprandi (1993): $\mathrm{pH}_{\text {water }}=0.890+0.922 \mathrm{pH}_{\mathrm{CaCl}}\left(r^{2}=0.97, p\right.$ $<0.05$ ). The SMAF scoring curve for $\mathrm{K}$ (Wienhold et al., 2009) is consistent with $\mathrm{K}$ recommendation classes adopted in Brazil (van Raij et al., 1997).

In addition to individual indicator scores, an overall SQI was calculated by summing the scores and dividing by the number of indicators for each soil layer. The overall SQI was also subdivided into chemical ( $\mathrm{pH}, \mathrm{P}$, and $\mathrm{K}$ ), physical (BD and AGS), and biological (SOC, MBC, and $\mathrm{BG}$ ) sectors, as well as their relative contributions to the overall SQI. This approach identifies the management areas of greatest concern (i.e., lowest index scores) so that land managers can be given better guidance on how to most efficiently restore or improve $S Q$ at that specific location (Stott et al., 2013; Karlen et al., 2014b).

\section{Statistical Analysis}

An analysis of variance (ANOVA) was computed using the PROC GLM procedure to test the influence of the land use change within each site on individual soil indicators, SMAF scores, and overall SQI values. If the ANOVA $F$ statistic was significant $(p<0.05)$, the means were compared using Tukey's test $(p<0.05)$. The analyses were performed separately by depth. An additional ANOVA was computed to test the land use change effects at a regional scale (all sites simultaneously) on the overall SQI and SQI sectors scores for the 0 - to 30-cm layer. Means were also compared using Tukey's test $(p<0.05)$. Finally, regression analyses were performed using the PROC REG procedure between SMAF scores and SOC stocks within each site for the 0 - to 30-cm depth and between SMAF scores and VESS scores for sites with contrasting texture (Lat_21S: sandy soils; Lat_23S: clay soils). All statistical procedures were completed using SAS Version 9.3 (SAS Institute).

\section{RESULTS AND DISCUSSION Soil Chemical Indicators}

Soil chemical conditions were typical for tropical regions (Table 2). Soils of the Cerrado biome in south-central Brazil are highly weathered and characterized by high acidity and low nutrient availability, as shown by Lopes and Cox (1977).

Transitions from native vegetation to extensive pasture led to soil acidification and decreased nutrient levels, especially available P (Table 2). Soil acidification and nutrient depletions were the result of long-term $(>30 \mathrm{yr}$ ) soil use with continuous grazing and the absence of lime and fertilizer inputs, as indicated by Cherubin et al. (2015) in a previous study at the same sites. Higher K levels under pasture at Lat_21S and Lat_23S could be attributed to several factors such as greater $\mathrm{K}$ cycling, lower $\mathrm{K}$ losses (Kayser and Isselstein, 2005), and release of non-exchangeable $\mathrm{K}$ forms by the aggressive root systems of the grasses (Rosolem et al., 2012).

The algorithms used in SMAF were able to detect score changes for the chemical indicators under tropical conditions in Brazil (Table 3). As expected, we needed to add new "crop factors" into the SMAF spreadsheet labeled Brazilian Cerrado vegetation, Atlantic Forest vegetation, Brazilian tropical grasses (Brachiaria spp. and Cynodon spp.), and sugarcane. The SMAF scoring curves for $\mathrm{pH}$ and $\mathrm{P}$ have a parabolic shape, denoting an optimum range, which takes into account crop-specific critical limits to sustain plant growth without causing deleterious environmental impacts (e.g., fresh water contamination), as stressed by Andrews et al. (2004). In general, the results showed that conversion of native vegetation to pasture decreased $\mathrm{pH}$ scores (average from 0.92 to 0.69 ) and P scores (average from 0.90 to 0.62 ), mainly at the Lat_17S and Lat_21S sites (Table 3). The SMAF scoring curves for $\mathrm{K}$ also have a parabolic shape; however, they were set up using a general response of crops to soil K levels according to Wienhold et al. (2009). Therefore, the K scores were lower than the $\mathrm{pH}$ and $\mathrm{P}$ scores, especially at Lat_17S (more weathered soil), with averages of 0.38 and 0.19 under native vegetation and pasture, respectively. For Lat_21S and Lat_23S, K scores increased from native vegetation (average from 0.67 and 0.76 ) to pasture (average from 0.76 and 0.96 ) (Table 3).

Land use changes from pasture to sugarcane promoted overall improvements in soil chemical indicators. Sugarcane management including lime application resulted in higher $\mathrm{pH}$ values at all sites, with the average increasing from 4.6 (pasture) to 5.6 (sugarcane) (Table 2) and average $\mathrm{pH}$ scores from 0.69 (pasture) to 0.86 (sugarcane) (Table 3). Applications of mineral fertilizer and complementary organic residues in sugarcane fields increased P levels and scores (from 0.47 to 0.81 ) and increased or maintained K levels (average scores 0.48 for pasture and 0.47 for sugarcane) at Lat_17S and Lat_21S. Although both P and K levels improved with sugarcane cultivation, they were still below the critical limits, $\mathrm{P}>16 \mathrm{mg} \mathrm{dm}^{-3}$ and $\mathrm{K}>120 \mathrm{mg} \mathrm{dm}^{-3}$, established by van Raij et al. (1997). In contrast, lower P and K levels and scores were found in the sugarcane field than the pasture at Lat_23S (Table 2), probably associated with the management of fertilization using an insufficient amount of organic residues (Table 1), as verified by Cherubin et al. (2015) and due to significant SOM depletions (Franco et al., 2015).

All measurements for $\mathrm{pH}, \mathrm{P}$, and $\mathrm{K}$ were concentrated at the increasing part of the SMAF parabolic curves, confirming that acidity and low plant-available $\mathrm{P}$ and $\mathrm{K}$ levels are the limiting factors for sugarcane production on Brazilian weathered soils.

\section{Soil Physical Indicators}

The land use change from native vegetation to pasture induced soil compaction by increasing BD values (Table 2). Many 
Table 2. Mean values of the soil quality indicators of $\mathrm{pH}, \mathrm{P}, \mathrm{K}$, bulk density (BD), macroaggregate stability(AGS), soil organic C (SOC), microbial biomass (MBC), and $\beta$-glucosidase activity (BG) from the 0- to 10-, 10- to 20-, and 20- to 30-cm soil layers from three sites under native vegetation (NV), pasture (PA), and sugarcane (SC) in south-central Brazil.

Mean indicator values

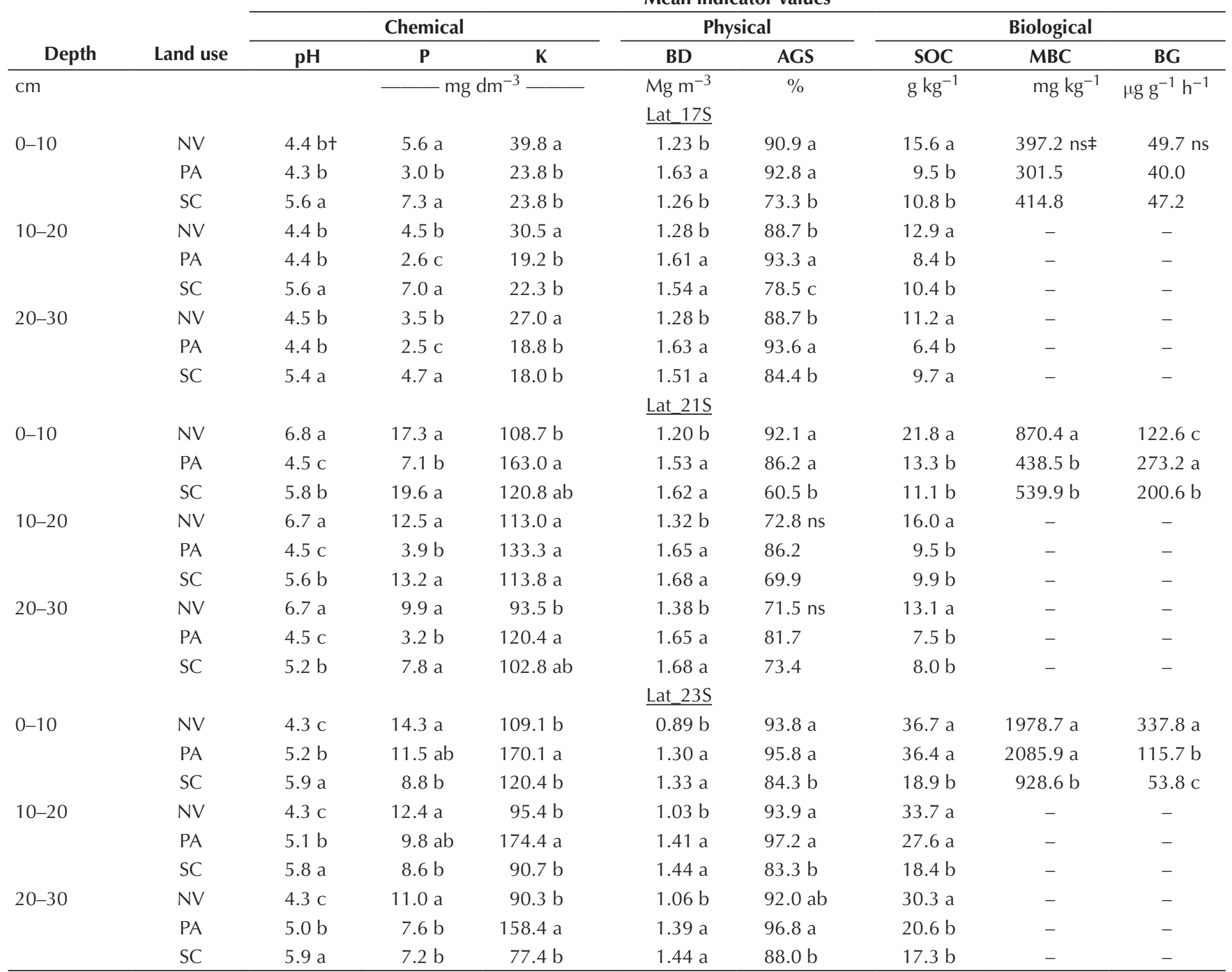

† Mean values $(n=9)$ in a column within a site and depth followed by the same letter do not differ significantly according to Tukey's test $(p<$ 0.05).

₹ ns, not significant.

studies have shown that cattle trampling is the major driver for soil compaction under pasture (e.g., Greenwood and McKenzie, 2001; Pietola et al., 2005). In addition, low pasture productivity (shoots and roots) has been verified under compacted soils, reducing $C$ inputs into the soil (Maia et al., 2009; Franco et al., 2015) and contributing to an increase in soil structural degradation. The SMAF scoring curves for BD (less-is-better sigmoidal shapes), which take into account texture and mineralogical classes (Andrews et al., 2004), were able to identify alterations to BD due to land use change effects (Table 3). The BD scores decreased from native vegetation (average 0.85 ) to pasture (average 0.44 ). Regarding macroaggregate stability (AGS), higher values were found under native vegetation and pasture, ranging from $>70 \%$ in sandy soils (Lat_21S) to $>90 \%$ in clay soils (Lat_23S). High AGS values are typically reported in studies on weathered Brazilian soils (e.g., Madari et al., 2005; Barthès et al., 2008), being associated primarily with a clay mineral com- position dominated by $\mathrm{Fe}$ and $\mathrm{Al}$ oxides and 1:1 mineral layering in these soils (Six et al., 2000). In addition, Franco (2015) verified that soil macrofauna abundance plays important role in the soil aggregation processes in tropical soils; therefore, greater AGS under native vegetation and pasture are consistent with a greater abundance of soil engineering invertebrates (i.e., earthworms and termites) in these areas (Franco, 2015). The SMAF scoring curves for AGS (more-is-better sigmoidal shapes) takes into account differences in SOM, texture, and Fe oxide content (Andrews et al., 2004). However, for all possible variations of these factors, the maximum score (1.0) is assigned when AGS values are $>50 \%$ (the threshold value for which soil structural stability is optimum for environment protection and productivity goals). Therefore, using the current SMAF scoring curves, the AGS score was a non-sensitive indicator to detect land use change impacts in tropical soils, reaching a score of practically 1.0 for all sites (Table 3). Macroaggregate stability has been 
Table 3. Scores of the soil quality indicatorsof $\mathrm{pH}, \mathrm{P}, \mathrm{K}$, bulk density (BD), macroaggregate stability(AGS), soil organic C (SOC), microbial biomass $(\mathrm{MBC})$, and $\beta$-glucosidase activity (BG) from the 0 - to 10-, 10- to 20-, and 20- to 30-cm soil layers from three sites under native vegetation (NV), pasture (PA), and sugarcane (SC) in south-central Brazil.

\begin{tabular}{|c|c|c|c|c|c|c|c|c|c|}
\hline \multirow[b]{3}{*}{ Depth } & \multirow[b]{3}{*}{ Land use } & \multicolumn{8}{|c|}{ Indicator SMAF scores } \\
\hline & & \multicolumn{3}{|c|}{ Chemical } & \multicolumn{2}{|c|}{ Physical } & \multicolumn{3}{|c|}{ Biological } \\
\hline & & $\mathrm{pH}$ & $\mathbf{P}$ & K & BD & AGS & SOC & MBC & BG \\
\hline \multicolumn{10}{|l|}{$\mathrm{cm}$} \\
\hline \multirow{4}{*}{$0-10$} & & & & & $\underline{\text { Lat_17S }}$ & & & & \\
\hline & NV & $0.99 \mathrm{a} t$ & $0.85 \mathrm{a}$ & $0.44 \mathrm{a}$ & $0.73 \mathrm{a}$ & $1.00 \mathrm{~ns} \ddagger$ & $0.96 \mathrm{a}$ & $1.00 \mathrm{~ns}$ & $0.19 \mathrm{~ns}$ \\
\hline & PA & $0.50 \mathrm{c}$ & $0.39 \mathrm{~b}$ & $0.22 \mathrm{c}$ & $0.38 \mathrm{~b}$ & 1.00 & $0.78 \mathrm{~b}$ & 0.95 & 0.15 \\
\hline & SC & $0.89 \mathrm{~b}$ & $0.78 \mathrm{a}$ & $0.29 \mathrm{~b}$ & $0.71 \mathrm{a}$ & 1.00 & $0.74 \mathrm{~b}$ & 1.00 & 0.19 \\
\hline \multirow[t]{3}{*}{$10-20$} & NV & $0.99 \mathrm{a}$ & $0.77 \mathrm{a}$ & $0.36 \mathrm{a}$ & $0.61 \mathrm{a}$ & $1.00 \mathrm{~ns}$ & $0.88 \mathrm{a}$ & - & - \\
\hline & $\mathrm{PA}$ & $0.52 \mathrm{c}$ & $0.29 \mathrm{~b}$ & $0.18 \mathrm{c}$ & $0.41 \mathrm{~b}$ & 1.00 & $0.65 \mathrm{~b}$ & - & - \\
\hline & SC & $0.89 \mathrm{~b}$ & $0.78 \mathrm{a}$ & $0.28 \mathrm{~b}$ & $0.32 \mathrm{~b}$ & 1.00 & $0.69 \mathrm{~b}$ & - & - \\
\hline \multirow[t]{4}{*}{$20-30$} & NV & $1.00 \mathrm{a}$ & $0.60 \mathrm{a}$ & $0.33 \mathrm{a}$ & $0.63 \mathrm{a}$ & $1.00 \mathrm{~ns}$ & $0.77 \mathrm{a}$ & - & - \\
\hline & PA & $0.54 \mathrm{c}$ & $0.26 \mathrm{~b}$ & $0.18 \mathrm{c}$ & $0.40 \mathrm{~b}$ & 1.00 & $0.40 \mathrm{c}$ & - & - \\
\hline & SC & $0.79 \mathrm{~b}$ & $0.54 \mathrm{a}$ & $0.23 \mathrm{~b}$ & $0.32 \mathrm{~b}$ & 1.00 & $0.63 \mathrm{~b}$ & - & - \\
\hline & & & & & Lat_21S & & & & \\
\hline \multirow[t]{3}{*}{ 0-10 } & NV & $0.79 \mathrm{~b}$ & $1.00 \mathrm{a}$ & $0.68 \mathrm{~b}$ & $0.98 \mathrm{a}$ & $1.00 \mathrm{~ns}$ & $1.00 \mathrm{a}$ & $1.00 \mathrm{~ns}$ & $0.91 \mathrm{~b}$ \\
\hline & PA & $0.63 \mathrm{c}$ & $0.88 \mathrm{~b}$ & $0.81 \mathrm{a}$ & $0.56 \mathrm{~b}$ & 1.00 & $0.96 \mathrm{a}$ & 1.00 & $1.00 \mathrm{a}$ \\
\hline & SC & $0.91 \mathrm{a}$ & 0.99 a & $0.71 \mathrm{ab}$ & $0.39 \mathrm{c}$ & 1.00 & $0.88 \mathrm{~b}$ & 1.00 & $1.00 \mathrm{a}$ \\
\hline \multirow[t]{3}{*}{$10-20$} & NV & $0.83 \mathrm{a}$ & $0.98 \mathrm{a}$ & $0.70 \mathrm{a}$ & $0.94 \mathrm{a}$ & $0.99 \mathrm{~ns}$ & $0.98 \mathrm{a}$ & - & - \\
\hline & PA & $0.60 \mathrm{~b}$ & $0.56 \mathrm{~b}$ & $0.75 \mathrm{a}$ & $0.35 \mathrm{~b}$ & 1.00 & $0.78 \mathrm{~b}$ & - & - \\
\hline & SC & $0.89 \mathrm{a}$ & 0.96 a & $0.69 \mathrm{a}$ & $0.33 \mathrm{~b}$ & 0.99 & $0.81 \mathrm{~b}$ & - & - \\
\hline \multirow[t]{4}{*}{$20-30$} & NV & $0.82 \mathrm{a}$ & $0.96 \mathrm{a}$ & $0.62 \mathrm{~b}$ & $0.85 \mathrm{a}$ & $1.00 \mathrm{~ns}$ & $0.95 \mathrm{a}$ & - & - \\
\hline & PA & $0.63 \mathrm{~b}$ & $0.43 \mathrm{c}$ & $0.72 \mathrm{a}$ & $0.36 \mathrm{~b}$ & 1.00 & $0.54 \mathrm{~b}$ & - & - \\
\hline & SC & $0.71 \mathrm{ab}$ & $0.80 \mathrm{~b}$ & $0.65 \mathrm{ab}$ & $0.33 \mathrm{~b}$ & 0.99 & $0.61 \mathrm{~b}$ & - & - \\
\hline & & & & & Lat_23S & & & & \\
\hline \multirow[t]{3}{*}{$0-10$} & NV & $0.96 \mathrm{~ns}$ & $0.99 \mathrm{a}$ & $0.79 \mathrm{~b}$ & $0.99 \mathrm{a}$ & $1.00 \mathrm{~ns}$ & $1.00 \mathrm{~ns}$ & $1.00 \mathrm{~ns}$ & $1.00 \mathrm{a}$ \\
\hline & PA & 0.96 & $0.95 \mathrm{ab}$ & $0.96 \mathrm{a}$ & $0.61 \mathrm{~b}$ & 1.00 & 1.00 & 1.00 & $0.84 \mathrm{~b}$ \\
\hline & SC & 0.89 & $0.86 \mathrm{~b}$ & $0.84 \mathrm{~b}$ & $0.58 \mathrm{~b}$ & 1.00 & 0.98 & 1.00 & $0.23 \mathrm{c}$ \\
\hline \multirow[t]{3}{*}{$10-20$} & NV & $0.97 \mathrm{a}$ & $0.99 a$ & $0.76 \mathrm{~b}$ & $0.96 \mathrm{a}$ & $1.00 \mathrm{~ns}$ & $1.00 \mathrm{a}$ & - & - \\
\hline & PA & $0.91 \mathrm{ab}$ & $0.95 \mathrm{a}$ & $0.97 \mathrm{a}$ & $0.46 \mathrm{~b}$ & 1.00 & $1.00 \mathrm{a}$ & - & - \\
\hline & SC & $0.87 \mathrm{~b}$ & $0.84 \mathrm{~b}$ & $0.73 \mathrm{~b}$ & $0.39 \mathrm{~b}$ & 1.00 & $0.98 \mathrm{~b}$ & - & - \\
\hline \multirow[t]{3}{*}{$20-30$} & NV & $0.97 \mathrm{~ns}$ & $0.98 \mathrm{a}$ & $0.74 \mathrm{~b}$ & $0.97 \mathrm{a}$ & $1.00 \mathrm{~ns}$ & $1.00 \mathrm{a}$ & - & - \\
\hline & PA & 0.89 & $0.87 \mathrm{ab}$ & $0.94 \mathrm{a}$ & $0.45 \mathrm{~b}$ & 1.00 & 0.99 a & - & - \\
\hline & SC & 0.89 & $0.76 \mathrm{~b}$ & $0.67 \mathrm{~b}$ & $0.33 \mathrm{~b}$ & 1.00 & $0.98 \mathrm{~b}$ & - & - \\
\hline
\end{tabular}

† Mean values $(n=9)$ in a column within a site and depth followed by the same letter do not differ significantly according to Tukey's test $(p<$ $0.05)$.

₹ ns, not significant.

globally used as a SQ indicator (Cardoso et al., 2013; Karlen et al., 2013, 2014b; Stott et al., 2013; Zornoza et al., 2015) due to its crucial role in $\mathrm{C}$ stabilization and protection, mediating soil physical processes related to water and air dynamics, and providing resistance against soil erosion. Therefore, additional SMAF scoring curves for AGS need to be developed for detecting smaller changes caused by recent land use and management under well-aggregated tropical soils.

Conversions from pasture to sugarcane have been done through intensive mechanization, raising a concern about soil compaction. Although BD had no significant differences between sugarcane and pasture, the values found in sugarcane $(>1.2$ $\mathrm{Mg} \mathrm{dm}^{-3}$ for clay soil and $>1.6 \mathrm{Mg} \mathrm{dm}^{-3}$ for sandy soils; Table 2 ) are considered critical for sustaining adequate plant growth, as shown by Reynolds et al. (2002). Using SMAF, the average $\mathrm{BD}$ score was 0.41 (Table 3), confirming that soil compaction is one of the major drivers of SQ degradation under sugarcane fields. Tillage operations performed during sugarcane replanting (about every 5 yr) alleviated soil compaction (i.e., decreased $\mathrm{BD})$, but this positive effect was limited to the surface layer (10$\mathrm{cm}$ depth) in the sugarcane field at Lat_17S and probably has short-term persistence as verified in other Brazilian soils by Silva et al. (2012). In addition, soil tillage promoted the breakup of the macroaggregates and SOC and macrofauna losses, decreasing AGS values under sugarcane production (Table 2). As discussed above, even though AGS depletions were statistically significant, AGS scores were close to 1 , generally equal to those found under native vegetation and pasture (Table 3 ).

\section{Soil Biological Indicators}

Greater SOC contents were found under native vegetation, ranging from 11.2 to $36.7 \mathrm{~g} \mathrm{~kg}^{-1}$ (Table 2), depending on soil taxonomic class, texture, and climate. These factors are taken into account in the SMAF scoring curves (more-is-better sigmoi- 
dal shapes) for SOC thus accounting for inherent soil characteristics that can affect the score (Andrews et al., 2004). The land use change from native vegetation to pasture decreased the SOC content (Table 2) and average scores from 0.95 to 0.79 (Table $3)$. These SOC losses in tropical regions are well documented in the literature (Maia et al., 2009; Mello et al., 2014; Franco et al., 2015) as a result of conversion processes and low $C$ inputs due to low grass productivity and inadequate grazing management. The $\mathrm{MBC}$ values were high at all sites, especially in higher clay soil (Lat_23S). Conversions from native vegetation to pasture tended to decrease MBC at Lat_17S and Lat_21S (Table 2), similar to that observed for SOC, confirming the close relationship between MBC and SOC $(r=0.88, p<0.01)$. Regardless of the site and the effects of land use change, the SMAF scores for MBC ranged from 0.95 to 1.0 , without differences among land uses (Table 3). These results are consistent with the study of Lopes et al. (2013), who defined $M B C$ values $>375 \mathrm{mg} \mathrm{kg}^{-1}$ as high under clayey Oxisols in the Brazilian Cerrado. The BG activity responses to land use change were statistically different within each site. At Lat_23S, BG values significantly decreased from native vegetation to pasture. In contrast, a significantly higher BG was found under pasture than native vegetation at Lat_21S, probably associated with higher $\mathrm{pH}$ under native vegetation soil (Table 2). The SMAF scores for BG decreased from native vegetation (1.0) to pasture (0.84) at Lat_23S, there was a slight increase from native vegetation (0.91) to pasture (1.0) at Lat_21S, and there were no significant differences at Lat_17S, where the lowest scores were observed (Table 3). The SMAF scoring curves for $B G$ were sensitive to alterations induced by land use change. The inclusion of a data set from Brazilian Cerrado soils for the development and validation of the SMAF BG algorithms (Stott et al., 2010) probably contributed to the good performance for the soils of this study. In addition, previously Lopes et al. (2013) had verified that critical limits for BG activity defined as a function of crop yield and SOC in clayey Brazilian Oxisols were consistent with SMAF BG scores (i.e., values in the low and high interpretative classes were equivalent to SMAF BG scores of 0.85 and 0.32 , respectively).
Short-term transitions from pasture to sugarcane $(<5 \mathrm{yr}$, see Table 1) did not promote significant SOC changes at Lat_17S and Lat_21S (Table 2). However, after $>20$ yr of sugarcane including approximately $10 \mathrm{yr}$ of burning preharvest, significant SOC depletion and reduced MBC and BG activity at Lat_23S (Table 2) were observed. For that site, SOC scores showed a slight decrease from pasture (1.0) to sugarcane (0.98), MBC scores showed no differences, and BG scores had marked depletion under sugarcane $(0.23)$. These results are consistent with large studies recently performed in south-central Brazil by Mello et al. (2014) and Bordonal et al. (2015).

\section{Overall Soil Quality Index and Sectors}

Overall SQI and SQI sectors (i.e., chemical, physical, and biological) for each depth and site are shown in Fig. 1 and at a regional scale (Fig. 2) for the 0 - to $30-\mathrm{cm}$ depth. The SQI computed for each depth $(0-10,10-20$, and $20-30 \mathrm{~cm})$ indicated that $S Q$ decreased with depth, regardless of the land use and site. Several factors contributed to improving SQ in the first centimeters, such as inputs of $\mathrm{C}$ from litter and crop residues on the soil
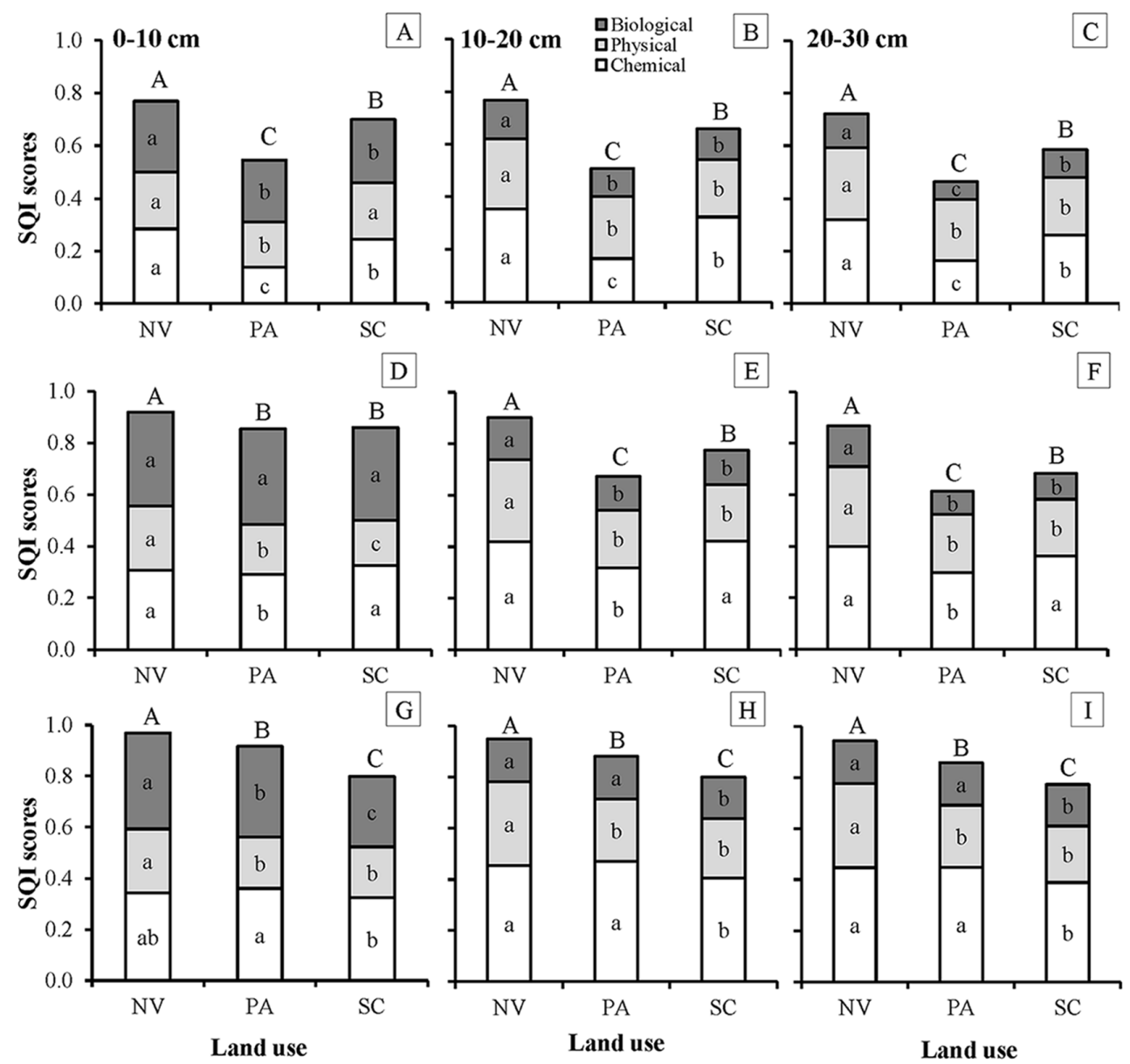

Fig. 1. Overall soil quality index (SQI) scores and the contribution of chemical, physical, and biological attributes to the overall SQI under native vegetation (NV), pasture (PA), and sugarcane (SC) for the 0 - to 10- (left), 10- to 20- (center), and 20- to 30-cm (right) layers at (A,B,C) Lat_17S, (D,E,F) Lat_21S, and $(\mathrm{G}, \mathrm{H}, \mathrm{I})$ Lat_23S in south-central Brazil. Mean SQI scores within a site in the same depth followed by the same uppercase letter do not differ significantly according to Tukey's test $(p<0.05)$. Mean sectors' (chemical, physical, and biological) contribution within a site in the same depth followed by the same lowercase letter do not differ significantly according to Tukey's test $(p<0.05)$. 
surface, greater biological and biochemical activity, higher nutrient cycling and fertilizer inputs, better soil structure and physical resistance, as well as better soil resilience to stress due to animal trampling and machinery traffic. We highlighted that SMAF scores calculated for deeper layers $(>15-\mathrm{cm}$ depth) must be carefully interpreted because SMAF scoring algorithms were originally developed for nearsurface soils.

The highest SQI scores were verified in the native vegetation soils and ranged from 0.72 to 0.77 at Lat_17S, from 0.87 to 0.92 at Lat_21S, and from 0.94 to 0.97 at Lat_23S. At a regional scale, the average SQI suggests that these soils are functioning at $87 \%$ of their potential capacity for the 0- to 30-cm layer (Fig. 2). The SQI sectors were also higher under native vegetation for all studied sites and depths (Fig. 1 and 2). These results demonstrate that natural ecosystems are in dynamic balance, where chemical, physical, and biological attributes act cooperatively in such way that soils perform their functions properly.

Conversions from native vegetation to pasture promoted significant SQ degradation, with SQI values ranging from 0.51 to $0.77,0.61$ to 0.85 , and 0.86 to 0.92 at Lat_17S, Lat_21S, and Lat_23S, respectively. At the regional scale, the average SQI suggests that these soils are functioning at $70 \%$ of their potential capacity for the 0 - to $30-\mathrm{cm}$ layer (Fig. 2). Long-term land use with extensive pasture led to chemical impoverishment of the soil, increasing soil compaction with its deleterious impacts on soil physical processes and negative impacts on biological indicators driven by SOC depletions, as evidenced by SQI sector scores in Fig. 2b. Recent estimates suggest that $70 \%$ of Brazilian pasturelands are degraded or in the process of being degraded (Dias-Filho, 2014), and SQ degradation caused by inadequate management of pasture and animals is considered the major driver of this process. We believe that investigations using robust frameworks, such as SMAF, for assessing SQ or health under extensive pasture in Brazil could help farmers make the best decisions about more sustainable uses for their lands and guide the government's strategic planning for agricultural expansion and/or funding the adoption of strategies for recovery of degraded pasture areas (e.g., the Low-Carbon Agriculture program in Brazil).

The sugarcane expansion under pasturelands improved SQ at Lat_17S and Lat_21S. For these sites, the average SQI (0-30 $\mathrm{cm}$ ) showed that sugarcane soils are functioning at 65 and $77 \%$ their potential capacity (Fig. 1). At Lat_23S, although the SQI decreased under sugarcane, probably due to previous management involving burning preharvest and significant SOC losses (Franco et al., 2015) and current fertilization practices, the soil is functioning at $79 \%$ of its potential capacity (Fig. 1). At the
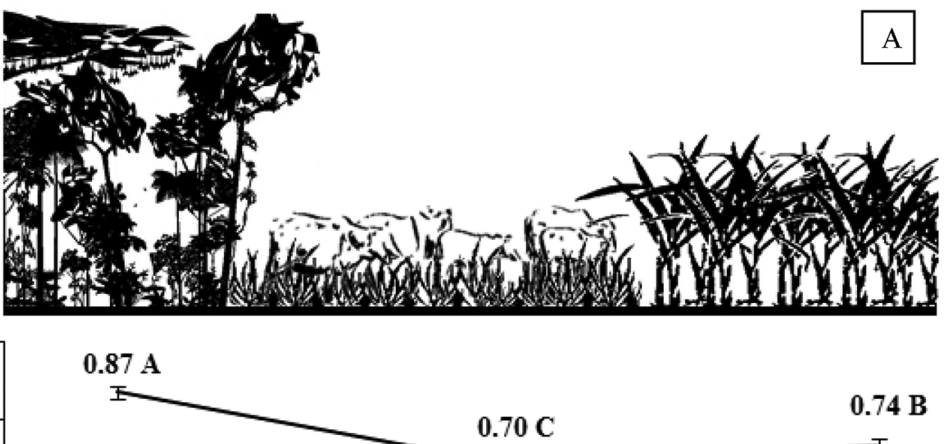

王

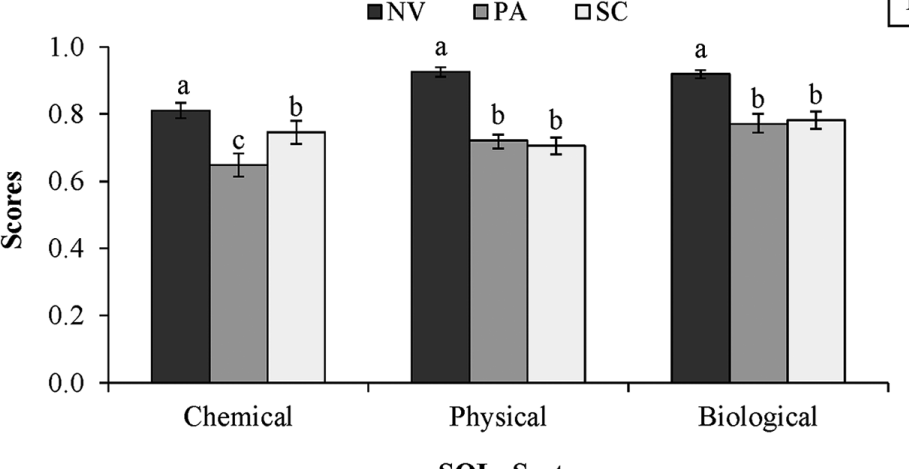

SQI - Sectors

Land Use

Fig. 2. (A) Overall soil quality index (SQI) scores and (B) SQI sector (chemical, physical, and biological) scores for the 0 - to $30-\mathrm{cm}$ layer at a regional scale of land use change native vegetation [NV]-pasture [PA]-sugarcane [SC]) for sugarcane expansion in Brazil. (he mean. +Mean SQI scores followed by the same uppercase letter do not differ significantly according to Tukey's test $(p<0.05)$. $\S$ Mean scores within an SQI sector (chemical, physical, or biological) followed by the same lowercase letter do not differ significantly according to Tukey's test $(p<0.05)$.

regional scale (Fig. 2), the SQI indicated that sugarcane expansion into extensive pasture led to slight but significant improvement in SQ. Therefore, sugarcane soils are functioning at 74\% of their potential capacity within the 0 - to 30 -cm layer. This SQ improvement was driven by inputs of lime and fertilizer, which significantly increased the chemical SQI sector scores (Fig. 2b). These findings demonstrate how important the proper management of fertilization is in agricultural systems for sustaining SQ in tropical regions. Physical and biological SQI sectors had no differences between sugarcane and pasture soils, which had average decreases of 22 and 15\% of their physical and biological functioning capacity compared with native vegetation soils.

Our SQ assessment, based on SMAF scores, suggests that sugarcane cultivation has improved SQ compared with extensive pasturelands. Therefore, sugarcane expansion reintegrates degraded pasturelands into a productive system, providing more economical and social benefits with positive environmental offsets (improving soil quality, saving greenhouse gas emissions [Mello et al., 2014; Bordonal et al., 2015], and alleviating de- 
forestation of natural ecosystems [Mello et al., 2014; Goldemberg et al., 2014]). However, to avoid future SQ declines in sugarcane fields, we recommend the adoption of management strategies (e.g., maintenance of sugarcane straw on the soil surface, application of organic residues as complementary fertilization, minimumtillage or no-till systems associated with crop rotation, controlled machinery traffic) that ensure proper soil fertility to achieve the nutritional demands of the sugarcane crop, improve soil C sequestration, and mitigate deleterious impacts from tillage and machine traffic on soil physical properties and processes.

\section{Overall Soil Quality Index vs. Soil Organic Carbon Stocks and Visual Evaluation of Soil Structure Scores}

Globally, SOC is the most common single indicator used for assessing the impacts of land use changes and agricultural management practices on SQ and its multiple ecosystem services (Cardoso et al., 2013; Zornoza et al., 2015). In Brazil, several studies have assessed the sustainability of biofuel crop expansion through SOC stock changes (Frazão et al., 2014; Mello et al., 2014; Franco et al., 2015). In the United States, the Soil Conditioning Index was adopted by the NRCS to investigate the effects of agricultural practices on SOC and to infer changes in SQ (NRCS, 2003). Zobeck et al. (2008, 2015) compared agricultural management effects using the Soil Conditioning Index and the SMAF SQI. They concluded that both methodologies were able to identify SQ changes; however, because SMAF includes several chemical, physical, and biological indicators, it provides more detailed information about SQ than the Soil Conditioning Index.

Linear regressions between SOC stocks and SQI scores obtained using SMAF are shown in Fig. 3. Soil organic C stocks explained between 53 and $78 \%$ of the variation in the overall SQI. These findings support two important statements:

1. Changes in SOC stocks result in modifications in the physical, chemical, and biological attributes of $S Q$, which

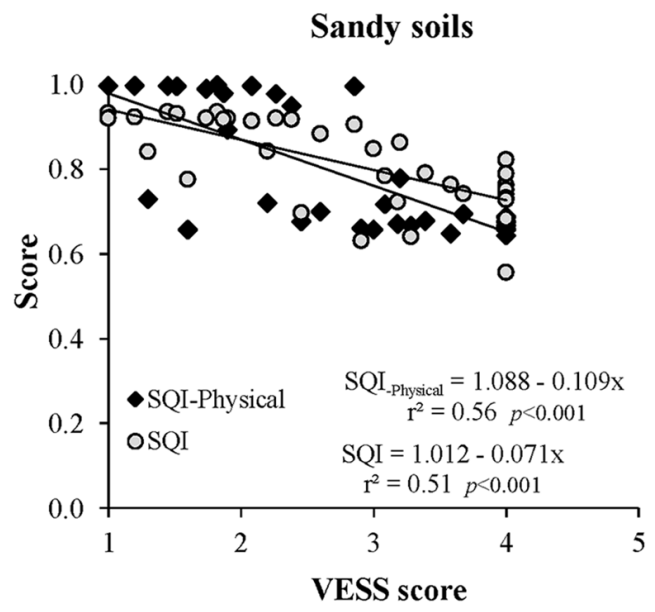

Fig. 3. Relationship between soil organic $\mathrm{C}$ stocks and overall soil quality index (SQI) scores for the 0 - to $30-\mathrm{cm}$ layer under land use change (native vegetation-pasturesugarcane) at three sites (Lat_17S, Lat_21S, and Lat_23S) in south-central Brazil. are encompassed in the SMAF SQI scores, supporting SOC as a universal indicator of SQ. However, when multiple indicators are used together, the SQ assessment becomes more accurate and enables identification of which critical conditions need priority management (e.g., soil fertility, soil compaction, biological activity, etc.).

2. These strong positive correlations validated SQI scores because SOC stock is broadly recognized as a suitable endpoint for environmental protection and crop productivity management goals.

We also verified a significant relationship of the SQI physical sector and overall SQI scores with VESS scores (Fig. 4). Our results showed that the variation in the SQI physical sector and overall SQI can be explained by VESS at 56 and $51 \%$ under sandy soils and at 32 and $25 \%$ under clay soils, respectively. Using the equations shown in Fig. 4 and the critical value of VESS $=3$, it was verified that the SQI physical sector and overall SQI reached values that correspond with 76 and $82 \%$ of physical functioning and 80 and $89 \%$ of overall functioning, respectively, for sandy and clay soils. We assume that a sharper decline in SQI physi-

\section{Clay soils}

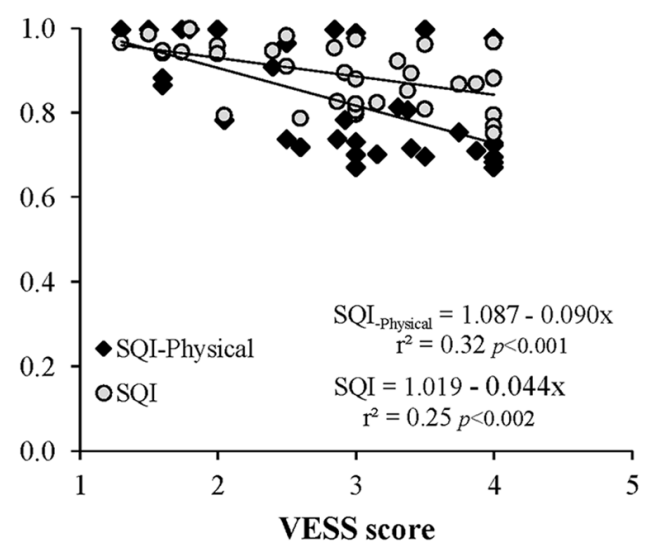

Fig. 4. Relationship among Visual Evaluation of Soil Structure (VESS) scores, overall soil quality index (SQI), and SQI physical sector scores under native vegetation, pasture, and sugarcane in south-central Brazil. 
cal sector and SQI scores must be observed when VESS scores are $>4$, which were not found for the studied sites. These results suggest that VESS measures more than the soil structural quality, with the advantages of being an on-farm method, simple to perform, and easy to understand (Guimarães et al., 2011; Ball et al., 2013; Mueller et al., 2013). Therefore, the VESS method could be used as a complementary tool for monitoring SQ in areas undergoing land use change for sugarcane expansion in Brazil. In addition, we suggest that VESS could be further included into the SMAF or used to replace other soil physical properties. Thereby, studies in a wide range of soils and agricultural managements systems are necessary to developed reliable SMAF scoring curves for VESS.

\section{CONCLUSIONS}

This study was the first application of SMAF for assessing SQ changes in Brazil and confirmed our hypothesis that SMAF would be sensitive enough to detect SQ changes associated with sugarcane expansion. In general, the SMAF scoring curves developed primarily on North American soils properly assigned scores for the soil chemical, physical, and biological indicators included in this study. The SMAF indicator scores were useful for evaluating which sectors require priority management, while the overall SQI score integrated all sectored information into a single value, enabling the detection of global SQ changes induced by land use change impacts. Overall, the SQI calculated by SMAF was positively correlated with SOC stock $\left(r^{2}=0.53-0.78\right)$, which is recognized for its multiple ecosystem functions. In addition, SQI was negatively correlated with VESS scores $\left(r^{2}=0.25-0.51\right)$, a simpler semi-quantitative method that has shown potential for on-farm monitoring of SQ changes. Therefore, the SMAF was a reliable and efficient tool to detect land use change effects on SQ under Brazilian tropical conditions. However, futures studies are encouraged to adjust and validate SMAF algorithms using data sets from tropical soils and expanding its use around the world.

Our findings suggest that native vegetation land use had the greatest $S Q$, with soils functioning on average at $87 \%$ of their potential capacity. Replacing native vegetation by pasture decreased SQ to $70 \%$ of its potential capacity. Land use changes from pasture to sugarcane induced slight improvements in SQ, mainly driven by increasing soil chemical quality. Overall, sugarcane soils are functioning at $74 \%$ of their potential capacity. Based in this study, management strategies that sustain proper soil fertility for sugarcane growth, increase soil C sequestration, and alleviate soil compaction and erosion are recommended to improve SQ and the sustainability of sugarcane production in Brazil.

\section{ACKNOWLEDGMENTS}

Maurício R. Cherubin and André L.C. Franco thank São Paulo Research Foundation (FAPESP) for research grants (Processes 2013/17581-6, 2014/16612-8, and 2012/22510-8). Cássio A. Tormena thanks CNPqBrazil for the scholarship granted as a visiting scientist at the USDAARS National Laboratory for Agriculture and the Environment, Ames, IA. The USDA prohibits discrimination in all its programs and activities. The USDA is an equal opportunity provider and employer.

\section{REFERENCES}

Adami, M., B.F.T. Rudorff, R.M. Freitas, D.A. Aguiar, M. Sugawara, and M.P. Mello. 2012. Remote sensing time series to evaluate direct land use change of recent expanded sugarcane crop in Brazil. Sustainability 4:574-585. doi: 10.3390/su4040574

Andrews, S.S., D.L. Karlen, and C.A. Cambardella. 2004. The Soil Management Assessment Framework: A quantitative soil quality evaluation method. Soil Sci. Soc. Am. J. 68:1945-1962. doi:10.2136/sssaj2004.1945

Ball, B.C., T. Batey, and L.J. Munkholm. 2007. Field assessment of soil structural quality: A development of the Peerlkamp test. Soil Use Manage. 23:329337. doi:10.1111/j.1475-2743.2007.00102.x

Ball, B.C., L.J. Munkholm, and T. Batey. 2013. Applications of visual soil evaluation. Soil Tillage Res. 127:1-2. doi:10.1016/j.still.2012.12.002

Barthès, B.G., E. Kouakoua, M.C. Larré-Larrouy, T.M. Razafimbelo, E.F. de Luca, A. Azontonde, et al. 2008. Texture and sesquioxide effects on waterstable aggregates and organic matter in some tropical soils. Geoderma 143:14-25. doi:10.1016/j.geoderma.2007.10.003

Bordonal, R.O., R. Lal, D.A. Aguiar, E.B. Figueiredo, L.I. Perillo, M. Adami, et al. 2015. Greenhouse gas balance from cultivation and direct land use change of recently established sugarcane (Saccharum officinarum) plantation in south-central Brazil. Renew. Sustain. Energy Rev. 52:547556. doi:10.1016/j.rser.2015.07.137

Cardoso, E.J.B.N., R.L.F. Vasconcellos, D. Bini, M.Y.H. Miyauchi, C.A. Santos, P.R.L. Alves, et al. 2013. Soil health: Looking for suitable indicators. What should be considered to assess the effects of use and management on soil health? Sci. Agric. 70:274-289. doi:10.1590/S0103-90162013000400009

Cherubin, M.R., A.L.C. Franco, C.E.P. Cerri, D.M.S. Oliveira, C.A. Davies, and C.C. Cerri. 2015. Sugarcane expansion in Brazilian tropical soils: Effects of land-use change on soil chemical attributes. Agric. Ecosyst. Environ. 211:173-184. doi:10.1016/j.agee.2015.06.006

Ciprandi, M.A.O. 1993. Avaliação da metodologia de determinação da acidez ativa e potencial em solos do Rio Grande do Sul. M.S. thesis. Univ. Federal do Rio Grande do Sul, Porto Alegre, RS, Brazil.

Companhia Nacional de Abastecimento. 2015. Acompanhamento da safra brasileira: Cana-de-açúcar. Vol. 2. Safra 2015/16, n. 2. Conab, Brasília. http://conab.gov.br/OlalaCMS/uploads/arquivos/15_08_13_15_58_44_ boletim_cana_portugues_-_2o_lev_-_15-16.pdf (accessed 18 Aug. 2015).

Dias-Filho, M.B. 2014. Diagnóstico das pastagens no Brasil. Doc. 402. Embrapa Amazônia Oriental, Belém, PA, Brazil. http://ainfo.cnptia.embrapa.br/ digital/bitstream/item/102203/1/DOC-402.pdf (accessed 17 Aug. 2015).

Erkossa, T., F. Itanna, and K. Stahr. 2007. Indexing soil quality: A new paradigm in soil science research. Aust. J. Soil Res. 45:129-137. doi:10.1071/SR06064

FAO. 2015. FAOSTAT. [Database.] FAO, Rome. http://faostat3.fao.org/ home/E (accessed 17 Aug. 2015).

Fischer, G., S. Prieler, H. van Velthuizen, G. Berndes, A. Faaij, M. Londo, and M. Wit. 2010. Biofuel production potentials in Europe: Sustainable use of cultivated land and pastures: II. Land use scenarios. Biomass Bioenergy 34:173-187. doi:10.1016/j.biombioe.2009.07.009

Foley, J.A., R. DeFries, G.P. Asner, C. Barford, G. Bonan, S.R. Carpenter, et al. 2005. Global consequences of land use. Science 309:570-574. doi:10.1126/science.1111772

Franco, A.L.C. 2015. Soil engineering by macroinvertebrates: Controls on soil organic matter storage across land use change. Ph.D. diss. "Luiz de Queiroz" College of Agriculture, Univ. of São Paulo, São Paulo, SP, Brazil.

Franco, A.L.C., M.R. Cherubin, P.S. Pavinato, C.E.P. Cerri, J. Six, C.A. Davies, and C.C. Cerri. 2015. Soil carbon, nitrogen and phosphorus changes under sugarcane expansion in Brazil. Sci. Total Environ. 515-516:30-38. doi:10.1016/j.scitotenv.2015.02.025

Frazão, L.A., K. Paustian, C.E.P. Cerri, and C.C. Cerri. 2014. Soil carbon stocks under oil palm plantations in Bahia State, Brazil. Biomass Bioenergy 62:17. doi:10.1016/j.biombioe.2014.01.031

Fu, B., L. Zhang, Z. Xu, Y. Zhao, Y. Wei, and D. Skinner. 2015. Ecosystem services in changing land use. J. Soils Sediments 15:833-843. doi:10.1007/ s11368-015-1082-x

Gasparatos, A., G.P. von Maltitz, F.X. Johnson, L. Lee, M. Mathai, J.A. Puppim de Oliveira, and K.J. Willis. 2015. Biofuels in sub-Sahara Africa: Drivers, impacts and priority policy areas. Renew. Sustain. Energy Rev. 45:879901. doi:10.1016/j.rser.2015.02.006

Gee, G.W., and D. Or. 2002. Particle-size analysis. In: J.H. Dane and G.C. Topp, editors, Methods of soil analysis. Part 4. Physical methods. SSSA Book Ser. 
5. SSSA, Madison, WI. p. 255-293. doi:10.2136/sssabookser5.4.c12

Gelaw, A.M., B.R. Singh, and R. Lal. 2015. Soil quality indices for evaluating smallholder agricultural land uses in northern Ethiopia. Sustainability 7:2322-2337. doi:10.3390/su7032322

Goldemberg, J., F.F.C. Mello, C.E.P. Cerri, C.A. Davies, and C.C. Cerri. 2014. Meeting the global demand for biofuels in 2021 through sustainable land use change policy. Energy Policy 69:14-18. doi:10.1016/j.enpol.2014.02.008

Greenwood, K.L., and B.M. McKenzie. 2001. Grazing effects on soil physical properties and the consequences for pastures: A review. Aust. J. Exp. Agric. 41:1231-1250. doi:10.1071/EA00102

Guimarães, R.M.L., B.C. Ball, and C.A. Tormena. 2011. Improvements in the visual evaluation of soil structure. Soil Use Manage. 27:395-403. doi:10.1111/j.1475-2743.2011.00354.x

Kalu, S., M. Koirala, U.R. Khadka, and K.C. Anup. 2015. Soil quality assessment for different land use in the Panchase area of western Nepal. Int. J. Environ. Protect. 5:38-43. doi:10.5963/IJEP0501006

Karlen, D.L., S.S. Andrews, B.J. Wienhold, and T.M. Zobeck. 2008. Soil quality assessment: Past, present and future. J. Integr. Biosci. 6:3-14.

Karlen, D.L., C.A. Cambardella, J.L. Kovar, and T.S. Colvin. 2013. Soil quality response to long-term tillage and crop rotation practices. Soil Tillage Res. 133:54-64. doi:10.1016/j.still.2013.05.013

Karlen, D.L., M.J. Mausbach, J.W. Doran, R.G. Cline, R.F. Harris, and G.E. Schuman. 1997. Soil quality: A concept, definition, and framework for evaluation. Soil Sci. Soc. Am. J. 61:4-10. doi:10.2136/ sssaj1997.03615995006100010001x

Karlen, D.L., G.A. Peterson, and D.G. Westfall. 2014a. Soil and water conservation: Our history and future challenges. Soil Sci. Soc. Am. J. 78:1493-1499. doi:10.2136/sssaj2014.03.0110

Karlen, D.L., D.E. Stott, C.A. Cambardella, R.J. Kremer, K.W. King, and G.W. McCarty. 2014b. Surface soil quality in five midwestern cropland Conservation Effects Assessment Project watersheds. J. Soil Water Conserv. 69:393-401. doi:10.2489/jswc.69.5.393

Kayser, M., and J. Isselstein. 2005. Potassium cycling and losses in grassland systems: A review. Grass Forage Sci. 60:213-224. doi:10.1111/j.13652494.2005.00478.x

Lapola, D.M., R. Schaldacha, J. Alcamoa, A. Bondeaud, J. Kocha, C. Koelkinga, and J.A. Priess. 2010. Indirect land-use changes can overcome carbon savings from biofuels in Brazil. Proc. Natl. Acad. Sci. 107:3388-3393. doi:10.1073/pnas.0907318107

Lee, J., J.W. Hopmans, D.E. Rolston, S.G. Baer, and J. Six. 2009. Determining soil carbon stock changes: Simple bulk density corrections fail. Agric. Ecosyst. Environ. 134:251-256. doi:10.1016/j.agee.2009.07.006

Lopes, A.A.C., D.M.G. Souza, G.M. Chaer, F.B. Reis, Jr., W.J. Goedert, and I.C. Mendes. 2013. Interpretation of microbial soil indicators as a function of crop yield and organic carbon. Soil Sci. Soc. Am. J. 77:461-472. doi:10.2136/sssaj2012.0191

Lopes, A.S., and F.R. Cox. 1977. A survey of the fertility status of surface soils under "Cerrado" vegetation in Brazil. Soil Sci. Soc. Am. J. 41:742-747. doi:10.2136/sssaj1977.03615995004100040026x

Madari, B., P.L.O.A. Machado, E. Torres, A.G. Andrade, and L.I.O. Valencia. 2005. No tillage and crop rotation effects on soil aggregation and organic carbon in a Rhodic Ferralsol from southern Brazil. Soil Tillage Res. 80:185-200. doi:10.1016/j.still.2004.03.006

Maia, S.M.F., S.M. Ogle, C.E.P. Cerri, and C.C. Cerri. 2009. Effect of grassland management on soil carbon sequestration in Rondonia and Mato Grosso states, Brazil. Geoderma 149:84-91. doi:10.1016/j.geoderma.2008.11.023

Mello, F.F.C., C.E.P. Cerri, C.A. Davies, N.M. Holbrook, K. Paustian, S.M.F. Maia, et al. 2014. Payback time for soil carbon and sugar-cane ethanol. Nat. Clim. Change 4:605-609. doi:10.1038/nclimate2239

Mueller, L., G. Shepherd, U. Schindler, B.C. Ball, L.J. Munkholm, V. Hennings, et al. 2013. Evaluation of soil structure in the framework of an overall soil quality rating. Soil Tillage Res. 127:74-84. doi:10.1016/j.still.2012.03.002

Mukherjee, I., and B.K. Sovacool. 2014. Palm oil-based biofuels and sustainability in Southeast Asia: A review of Indonesia, Malaysia, and Thailand. Renew. Sustain. Energy Rev. 37:1-12. doi:10.1016/j.rser.2014.05.001

NRCS. 2003. Interpreting the Soil Conditioning Index: A tool for measuring soil organic matter trends. Soil Qual.-Agron. Tech. Note 16. Soil Quality Inst., Auburn, AL. http://www.nrcs.usda.gov/Internet/FSE_DOCUMENTS/ nrcs142p2_053273.pdf (accessed 20 July 2015).

Pietola, L., R. Horn, and M. Yli-Halla. 2005. Effects of trampling by cattle on the hydraulic and mechanical properties of soil. Soil Tillage Res. 82:99-108. doi:10.1016/j.still.2004.08.004

Reynolds, W.D., B.T. Bowman, C.F. Drury, C.S. Tan, and X. Lu. 2002. Indicators of good soil physical quality: Density and storage parameters. Geoderma 110:131-146. doi:10.1016/S0016-7061(02)00228-8

Rosolem, C.A., J.P.T.M.M. Vicentini, and F. Steiner. 2012. Potassium supply as affected by residual potassium fertilization in a Cerrado Oxisol. (In Portuguese, with English abstract.) Rev. Bras. Cienc. Solo 36:1507-1515. doi:10.1590/S0100-06832012000500015

Silva, S.G.C., A.P. da Silva, N.F.B. Giarola, C.A. Tormena, and J.C.M. Sá. 2012. Temporary effect of chiseling on the compaction of a Rhodic Hapludox under no-tillage. Rev. Bras. Cienc. Solo 36:547-555. doi:10.1590/S010006832012000200024

Six, J., E.T. Elliott, and K. Paustian. 2000. Soil structure and soil organic matter: II. A normalized stability index and the effect of mineralogy. Soil Sci. Soc. Am. J. 64:1042-1049. doi:10.2136/sssaj2000.6431042x

Soil Survey Staff. 2014. Keys to Soil Taxonomy. 12th ed. NRCS, Washington, DC. Stott, D.E., S.S. Andrews, M.A. Liebig, B.J. Wienhold, and D.L. Karlen. 2010. Evaluation of b-glucosidase activity as a soil quality indicator for the Soil Management Assessment Framework. Soil Sci. Soc. Am. J. 74:107-119. doi:10.2136/sssaj2009.0029

Stott, D.E., D.L. Karlen, C.A. Cambardella, and R.D. Harmel. 2013. A soil quality and metabolic activity assessment after fifty-seven years of agricultural management. Soil Sci. Soc. Am. J. 77:903-913. doi:10.2136/sssaj2012.0355

Swanepoel, P.A., C.C. du Preez, P.R. Botha, H.A. Snyman, and L. Habig. 2015. Assessment of tillage effects on soil quality of pastures in South Africa with indexing methods. Soil Res. 53:274-285. doi:10.1071/SR14234

Tabatabai, M.A. 1994. Soil enzymes. In: R.W. Weaver et al, editors, Methods of soil analysis. Part 2. Microbiological and biochemical properties. SSSA, Madison, WI. p. 775-833. doi:10.2136/sssabookser5.2.c37

Vance, E.C., P.C. Brookes, and D.S. Jenkinson. 1987. An extraction method for measuring microbial biomass C. Soil Biol. Biochem. 19:703-707. doi:10.1016/0038-0717(87)90052-6

van Raij, B., J.C. Andrade, H. Cantarella, and J.A. Quaggio. 2001. Análise química para avaliação da fertilidade de solos tropicais. Inst. Agron., Campinas, SP, Brazil..

van Raij, B., H. Cantarella, J.A. Quaggio, and A.M.C. Furlani. 1997. Recomendações de adubação e calagem para o estado de São Paulo. 2nd ed. rev. Boletim Técnico 100. Inst. Agron., Campinas, SP, Brazil.

Veum, K.S., K.A. Sudduth, R.J. Kremer, and N.R. Kitchem. 2015. Estimating a soil quality index with VNIR reflectance spectroscopy. Soil Sci. Soc. Am. J. 79:637-649. doi:10.2136/sssaj2014.09.0390

Wienhold, B.J., D.L. Karlen, S.S. Andrews, and D.E. Stott. 2009. Protocol for Soil Management Assessment Framework (SMAF) soil indicator scoring curve development. Renew. Agric. Food Syst. 24:260-266. doi:10.1017/ S1742170509990093

Wienhold, B.J., J.L. Pikul, M.A. Liebig, M.M. Mikha, G.E. Varvel, and J.W. Doran. 2006. Cropping systems effects on soil quality in the Great Plains: Synthesis from a regional project. Renew. Agric. Food Syst. 21:49-59. doi:10.1079/RAF2005125

Wright, C.K., and M.C. Wimberly. 2013. Recent land use change in the western Corn Belt threatens grasslands and wetlands. Proc. Natl. Acad. Sci. 110:4134-4139. doi:10.1073/pnas.1215404110

Zobeck, T.M., B. Halvorson, B.J. Wienhold, V. Acosta-Martinez, and D.L. Karlen. 2008. Comparison of two soil quality indexes to evaluate cropping systems in northern Colorado. J. Soil Water Conserv. 63:329-338. doi:10.2489/jswc.63.5.329

Zobeck, T.M., J.L. Steiner, D.E. Stott, S.E. Duke, P.J. Starks, D.N. Moriasi, and D.L. Karlen. 2015. Soil Quality Index comparisons using Fort Cobb, Oklahoma, watershed-scale land management data. Soil Sci. Soc. Am. J. 79:224-238. doi:10.2136/sssaj2014.06.0257

Zornoza, R., J.A. Acosta, F. Bastida, S.G. Domínguez, D.M. Toledo, and A. Faz. 2015. Identification of sensitive indicators to assess the interrelationship between soil quality, management practices and human health. Soil 1:173185. doi:10.5194/soil-1-173-2015 